\title{
The Effect of Oral Metalinguistic Corrective Feedback on Learners' Knowledge of Pronoun among Iranian EFL Learners
}

\author{
Fatemeh Azimi Amoli \\ Department of English Language and Literature, Ilam University, Ilam, Iran
}

\begin{abstract}
A great number of language learners claims that they are unable to produce the foreign language accurately without any grammatical errors at the end of their language course. In this study, the impact of oral metalinguistic corrective feedback, among various types of corrective feedback, on learners' pronoun accuracy was considered. The participants were 74 EFL learners (46 females, 28 males) studying English at Safir English language institutes in Tehran. In order to homogenize the learners, Key English Test (KET) test was given to them. 60 learners were selected for the study and 14 learners were removed. Participants were randomly divided into two groups. One group received metalinguistic feedback and the other group received explicit correction feedback. Grammatical judgment test was used as a pretest and posttest. Eight reading passages from "Select Readings" were another instrument that was used for training through jigsaw task in this study. Then t-test was run to check the significance of the mean difference between pretest and post-test of groups. The results show the priority of experimental group (which received oral metalinguistic feedback) on control group (which received explicit feedback).
\end{abstract}

Index Terms - direct corrective feedback, metalinguistic corrective feedback, knowledge of pronunciation

\section{INTRODUCTION}

Direct corrective feedback (DCF) and metalinguistic explanation (ME) organize two techniques of performing written and oral error correction. DCF gives the correct forms to students without giving feedback to learners. Conversely, metalinguistic exploration (ME) is a process which the students can use self-correction to correct their errors. However, metalinguistic CF will simplify learning when learners have implicit knowledge of a grammatical feature. According to Chandler (2003), metalinguistic CF gives learners an opportunity how to correct the form directly which they could not do that through explicit feedback. This will be very important for the learners have limited L2 proficiency and hard to enhance their oral abilities of the learners.

According to Ferris and Roberts (2001) and Chandler (2003), metalinguistic CF was more effective for learners to improve their errors. Thus, they had access to the corrections when revising, so they only needed to consider the corrections. Some evidences in the learning process have occurred when they used CF on grammatical accuracy in new writing. According to Ellis, Sheen, Murakami, and Takashima (2008), direct CF can enhance accuracy by themselves. Farrokhi and Sattarpour (2012) also took into account that direct corrective feedback has significant benefits in accuracy in the use of English articles for the learners who are not professional in writing. Truscott and Hsu (2008) stated that metalinguistic CF didn't improve accuracy in new writing. Moreover, direct CF has impact not only on revision but also on improving accuracy in grammar accuracy its effect is for a long-term time. This could help the learners' implicit L2 knowledge to have an opportunity for revision. Also, it focuses on one grammatical feature which can give an awareness to students the rule about how to develop explicit knowledge. This will occur if some types of errors are corrected. In previous researches, ME provided a metalinguistic description of some errors (as in Bitchener \& Knoch, 2010b). In both cases, it is needed to correct the errors in individual learners' work. No previous study has taken into account the oral metalinguistic on the knowledge of grammar accuracy in pronunciation. The ME can be seen as a form of direct consciousness-raising. Therefore, this study has types of consciousness-raising related to learners' comprehending of the target structure.

\section{SIGNIFICANCE OF THE STUDY}

The most studies have examined the impact of corrective feedback or metalinguistic feedback based of improvement in accuracy. They did not consider the learners' reply to the feedback they received while retelling. We discuss that if we examine oral error feedback helps learning pronoun knowledge, we need to understand how learners respond to the feedback. Due to the metalinguistic, we have to know if learners pay attention to the corrections and to comprehend the rule and whether they can use it by self-correcting the errors they have done. What are required are methods to investigate how learners have replied to the correction and its usage. There are some studies of learners' real 
involvement with oral correction and there isn't any oral feedback to investigate learners' knowledge of pronoun. Thus, it is important to consider this study through oral metalinguistic feedback.

\section{Statement of The Problem}

Recently, different kinds of corrective feedback have been suggested and many studies have been performed on these kinds of corrective feedback. The positive effect of corrective feedback on learning language has been illustrated but few studies have been performed on the impact of corrective feedback on the assessment of learners' knowledge of pronoun accuracy to be learned and learners have to be mastered in its accuracy. Some language learners think that they can't produce the foreign language accurately without any grammatical errors. In this study, the impact of metalinguistic corrective feedback on grammatical accuracy among foreign language learners was taken into account. In most Iranian EFL contexts, language learners are not skillful enough in English, specifically in producing grammatical sentences. Therefore, teachers are as a scaffold to assist learners to meet the requirement of oral problems by providing useful feedback on their learners' knowledge of grammar accuracy. Traditionally, in Iranian English Foreign Language (EFL) context, one of the best techniques is to give direct metalinguistic feedback to exercise on error treatment in speaking classes. Some of the previous studies have considered the impact of EF in improving students' speaking but there were few studies investigating the role of oral metalinguistic feedback on pronoun knowledge of learners, particularly through utilizing and providing metalinguistic clues on EFL learners' knowledge of pronoun. The current study emphasized only on the acquisition of the pronouns and how to improve second language (L2) learners' grammar accuracy, and tries to find proper teaching techniques in the acquisition of L2 pronouns.

\section{ReSEARCH QueSTIONS}

The researcher is attempt to response the following questions based on the findings:

1) Does explicit correction feedback have a significant effect on EFL students' grammar in pronoun?

2) Does metalinguistic feedback have a significant effect on EFL students' grammar in pronoun?

3) Does exposure to metalinguistic feedback in EFL learners lead to more enhancement in their knowledge of pronoun or explicit correction feedback?

\section{REVIEW OF LITERATURE}

A factor affecting language accuracy is corrective feedback that is given to students. As Lalande (1982) for indirect feedback and Bitchener and Knoch (2009) and Kubota (2013) for direct corrective feedback stated, this area of research is developing quickly. A research carried out about metalinguistic feedback is related to producing writing explicitly or implicitly. Explicit type of meta-linguistic feedback in writing refers to errors which can either be oral or written (Bitchener \& Knoch, 2009).

According to Kubota (1994), the result of his study supports the role of explicit meta-linguistic feedback in teaching grammatical rules. According to Ellis, Loewen, \& Erlam (2006), implicit and explicit forms of feedback also displayed useful impacts of meta-linguistic feedback on language acquisition. Other studies carried out by Bitchener, Young and Cameron (2005), and Sheen (2007) about different types of direct corrective feedback on second language writing. The findings of Sheen's study (2007) displayed enhancement for both treatment groups as an experimental group in the immediate post-tests, however, the direct meta-linguistic group did better in the delayed post-test. Moreover, Bitchener (2008) pointed out the effects of metalinguistic feedback on enhancing of the English article (the/a). The findings were about both oral and written meta-linguistic feedback in combination with direct error correction and those who received direct feedback performed better than the students in control group.

According to Petchprasert (2012), there are four types of oral feedback: (1) it supports students in acquiring of learning vocabulary and structures in context; (2) it provides information for both teachers and students for assessment; (3) it gives motivation to students to improve their performance, and (4) it can assist the students toward self-reliance in order to understand their own errors and guess how to correct them. When the corrective feedback occurs in foreign language classes, it helps students to learn more.

As Ebadi, Mohd Saad \& Abedalaziz (2014) stated, acquiring grammatical features in L2 is not easy for all the traits. Some traits are difficult to attain and cannot be observed by simple exposure to the language. Thus, the effect of teaching language learning in different forms of intervention should be examined. Moreover, the other study carried out by Bowles (2011) pointed out the weak interface position in cognitive psychology comprehend the impacts of implicit and explicit corrective feedback on acquisition of different grammatical features in ESL learners.

\section{METHOD}

\section{A. Participants}

The participants were 74 EFL learners (46 females, 28 males) studying English at Safir English language institutes in Tehran. All the participants were in intermediate level. They were all aged between 18 to 25 . In order to homogenize the learners, KET test was given to them. 60 learners were selected for the study and 14 learners were removed. The 
learners who were one standard deviation above the mean and one below the mean were selected for the intended study. There are two groups of subjects. Each one has 30 participants which one group received metalinguistic feedback and another received explicit correction feedback in their reply to test. There are both male and female students in this study. Grammatical judgment test was run as a pretest. Then, they received similar teaching and similar syllabus. At last, learners in both control group and experimental group received the posttest.

\section{B. Instruments}

Two instruments were used in this study, namely, KET, grammatical judgment test as a pretest and posttest. The KET (Key English Test) was administered to examine whether the participants are in the same level of language proficiency. In addition, according to Ellis (1991, p.181), grammatical judgment test was run among 10 EFL learners and then it was distributed among all participants.

\section{Procedures}

Firstly, 60 students from Safir institute were given grammatical judgment test which contains tense and pronoun. The testees, then, were divided in two 30-member groups on the basis of their obtained scores. Then, one of the groups was randomly chosen as experimental group to receive the treatment (Abdollahzadeh, 2016, p. 188).

Second, Jigsaw task was carried out for 30 participants in experimental and 30 in control group in six equal teams. Each team contains five persons to retell the reading passage based on jigsaw task. Two of learners completed the pieces of story. Paragraphs in the story were divided among the groups in order to retell them. Then, teacher corrected the participants' errors in the experimental group after carrying out the retelling the passage (metalinguistic feedback). Teacher only corrected the errors related to pronoun. In each session, they have taught one passage and after performing the task, teachers gave feedback to control group explicitly and experimental group received metalinguistic feedback (Richards, 2001 as cited in Nunan, 2003). The data was assessed through t-test.

\section{Design}

The design of the current study is Quasi-experimental design. In this study, a pre-test and post-test design were run and its emphasis is on metalinguistic feedback as an independent variable and grammatical accuracy as a dependent variable.

\section{FINDINGS}

Researcher analyzed the mean and standard deviation of both groups to check both groups were homogeneous before the treatment. Their mean scores of experimental and control groups in pretest were analyzed through t-test. Post-test was administered for both control and experimental groups to investigate differences finishing sessions. After gathering the data, t-test was run to check the significance of the mean difference between pretest and post-test of groups.

\section{RESULTS}

Data were analyzed using both descriptive and inferential statistics. Descriptive statistics contains the means, standard deviations, and frequency. T-test was carried out to investigate the mean differences of two groups of scores.

\section{A. Test of Variable Homogeneity}

Leven test represented the significant level of meaningfulness is 0.234 which show the variance of two groups are equal. In fact, 60 participants were selected as homogenous. To evaluate the homogeneity of regression coefficients (slope), a Levene test was used and as it has been shown in the Table 1, p-value is 0.234 that is higher than the significance level of 0.05 . As a result, it can be concluded that data follow homogeneity of covariate regression coefficients (slope).

TABLE 1

\begin{tabular}{cccc}
\multicolumn{4}{c}{ TEST OF HOMOGEGIETY OF VARIANCES } \\
\hline Levene statistic & Df 1 & Df 2 & Sig. \\
\hline 9.232 & 2 & 58 & 0.234 \\
\hline
\end{tabular}

\section{B. Kolmogorov-Smirnov Test of Normality}

In order to examine the normality of the groups, test of Kolmogorov-Smirnov has been used in Table 2 in the following: 
TABLE 2

ONE-SAMPLE KOLMOGOROV-SMIRNOV TEST

\begin{tabular}{ccc}
\hline $\mathrm{N}$ & & Data \\
\hline & & 60 \\
\hline Normal parameters & Mean & 15.20 \\
\hline Test statistic & Std. Deviation & 3.145 \\
\hline Asymp. Sig. (2-tailed) & & .215 \\
\hline
\end{tabular}

Test statistic is 0.215 and meaningful level is 0.07 which represents the distribution of scores is normal.

\section{INVESTIGATION OF THE RESEARCH QUESTIONS}

The research question sought to investigate whether oral metalinguistic feedback has any significant effect on knowledge of pronoun. Table 3, 4 summarizes the descriptive statistics for the learners' performance of experimental and control groups in pretest and posttest stage. Next, inferential statistics through t-test was run to examine the mean differences of two groups at pretest.

TABLE 3

DESCRIPTIVE STATISTICS OF EXPERIMENTAL GROUPS' GRAMMAR TEST JUDGMENT SCORE In PRE AND POST-TEST

\begin{tabular}{cccccc}
\hline Exp & $\mathrm{N}$ & Mean & Std.deviation & Minimum & Maximum \\
\hline Pre & 60 & 14.47 & 2.949 & 11 & 20 \\
\hline Post & 60 & 15.93 & 3.262 & 11 & 20 \\
\hline
\end{tabular}

Regarding Table 3, mean score and standard deviation of experimental group in pre-test is 14.47 and 2.949 , respectively. The minimum score of grammatical judgment test in pre-test of experimental group is 11 and the maximum score is 20. In addition, mean score and standard deviation of post-test in experimental group is 15.93 and 3.262 , respectively. The minimum score of grammatical judgment test in post-test of experimental group is 11. It should be taken into consideration that the learners in post-test of experimental group had greater mean score than pre-test of experimental group. It shows that treatment of metalinguistic feedback has the impact on the improving learners' knowledge of pronoun.

A. Descriptive Statistics of Grammar Test Judgment Scores of Control Group in Pre-test and Post-test

The obtained descriptive statistics of learners has been displayed in Table 4.

TABLE 4

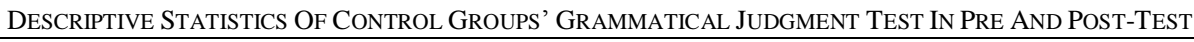

\begin{tabular}{cccccc}
\hline Control & $\mathrm{N}$ & Mean & Std.deviation & Minimum & Maximum \\
\hline Pre & 60 & 17.47 & 1.846 & 14 & 20 \\
\hline Post & 60 & 17.68 & 1.764 & 13 & 20 \\
\hline
\end{tabular}

Regarding Table 4, mean score and standard deviation of control group in pre-test is 17.47 and 1.764, respectively. The minimum score of grammatical judgment test in pre-test of control group is 14 and the maximum score is 20. In addition, mean score and standard deviation of post-test in control group is 17.68 and 1.764, respectively. The maximum and minimum score in post-test of control group is 13 and 20, respectively. It should be taken into consideration that the learners in post-test of control group had nearly the same mean score as pre-test of control group.

In order to investigate the first research question, a paired t-test was carried out to examine the effect of explicit correction feedback as a control group to check the knowledge of their pronoun. Tables 5 and 6 show the result of pretest and posttest in control group.

In order to know whether there is a significance difference between control and experimental group, a paired t-test was run in the following:

TABLE 5

INDEPENDENT SAMPLE T-TEST OF CONTROL GROUP'S PRE-TEST AND POST-TEST GRAMMATICAL JUdGMENT TEST SCORES

\begin{tabular}{ccccccc}
\hline Control group & $\mathrm{N}$ & Mean & Std. deviation & $\mathrm{T}$ & Df & Sig \\
\hline Pre & 60 & 15.39 & 1.653 & -3.216 & 14 & 0.006 \\
\hline Post & 60 & 15.75 & 3.432 & & & \\
\hline
\end{tabular}

Due to Table 5, t-test has been -3.216 and the significant level was 0.006 which displayed that there were no meaningful and significant difference among learners' knowledge of pronoun scores through grammatical judgment test at control group in pretest and posttest.

In the second research question, a paired t-test was done on the pretest and posttest of the metalinguistic feedback group. Tables 6 show the results in the following.

B. Comparisons of Experimental Group's Pre-test and Post-test Grammatical Judgment Test Mean Scores 
Mean scores of learners' knowledge of pronoun in pre-test and post-test of experimental group is 14.47 and 15.93 , respectively. Their mean comparisons of two groups have been run through independent t-test and have been shown in table 6.

TABLE 6

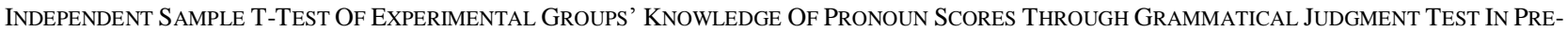
TEST AND POST-TEST

\begin{tabular}{lllllll}
\hline Exp test reading & $\mathrm{N}$ & Mean & Std. deviation & $\mathrm{T}$ & Df & Sig \\
\hline Pre & 60 & 14.46 & 2.984 & -1.324 & 14 & 0.20 \\
\cline { 1 - 5 } Post & 60 & 15.93 & 3.261 & & & \\
\hline
\end{tabular}

Based on Table 6, t-test is -1.324 and the significant level is 0.2 which displayed that there were meaningful and significant difference among knowledge of pronoun scores of experimental group learners in pre-test and post-test and shows the effectiveness of metalinguistic feedback.

To answer the third research question, an independent samples t-test was performed to compare the mean scores of posttest in both groups.

\section{Comparison between Learners' Scores in Experimental and Control Groups}

Mean scores of learners' pronoun accuracy through grammar judgment test in experimental group and control group are 19.00 and 15.93, respectively. The comparison of mean scores in two groups has been represented in table 7.

TABLE 7

PAIRED SAMPle T-Test OF PRE-TEST AND POST-TESt In EXPERIMENTAL AND CONTROL GRoups

\begin{tabular}{lllllll}
\hline test reading & $\mathrm{N}$ & Mean & Std. deviation & $\mathrm{T}$ & $\mathrm{Df}$ & Sig \\
\hline Exp & 60 & 18.23 & 3.145 & -4.625 & 58 & 0.08 \\
\hline Ctrl & 60 & 15.20 & 1.736 & & & \\
\hline
\end{tabular}

As Table 7 shows, t-test has been -4.625 and the significance level was 0.08 which represented there is a significant and meaningful difference between experimental and control groups' grammatical judgment test scores of learners in pre-test and post-test. The finding displayed that online learning has effect on oral metalinguistic feedback of the learners in experimental group.

\section{CONCLuSion AND Discussion}

Based on the results of this study, oral corrective feedback can reinforce the accuracy of EFL learners' pronoun. Also it can be concluded that receiving corrective feedback is effective way for Iranian English learners to comprehend their errors. In addition, the result showed metalinguistic corrective feedback has an effect on the learners' performance. This study tried to attain a better understanding of the role of oral corrective feedback in foreign language accuracy (pronoun). As a whole, results of the current study support teacher corrective feedback which was matched with the study of some researchers such as Bitchener (2008), Chandler (2003), and Ellis (2008), Ferris (1999). Furthermore, feedback strategies can be beneficial for learners. Moreover, the findings are on the contrary with the claim of Truscott who debated about the impact of corrective feedback. Truscott (1999) described that corrective feedback doesn't have any impact on improving student accuracy. In addition, Hsu and Truscott (2008) pointed out that decrease of error during revision is not a learning process and also treatment groups cannot improve students' ability through corrective feedback. The findings of this study elaborates that learners learned effectively from teacher corrective feedback by utilizing correct form of some previous errors each session. Thus, EFL learners decreased their grammatical errors. The findings of this study can illustrate empirical document about reducing of errors in learners' pronoun accuracy during the treatment period.

Regarding the first research question, metalinguistic feedback was influential on pronoun improvement of the Iranian EFL students. These results are congruent with the other research, carried out by Bitchener (2008), Ellis (2008), Lyster (2007), and Sheen (2007) and demonstrated that all students received oral metalinguistic feedback carried out better than control groups.

Due to the third research question, exposure to metalinguistic feedback in EFL learners lead to more explicit correction feedback because the learners can increase their knowledge of the language by this technique (Schmidt, 1993). It gives students information about their errors so that they can think critically about the structures of sentences. In addition, metalinguistic feedback usually contains information about preposition, verb, and relative pronoun for a speech episode. Schmidt's (2001) identified the significance role of students' attention to their linguistic knowledge and metalinguistic feedback and recognized the gap between their interlanguage and the target forms (errors).

\section{REFERENCES}

[1] Abdollahzadeh, S. (2016). The Effect of Metalinguistic Corrective Feedback on EFL Learners' Grammatical Accuracy. Journal of Language Teaching and Research, 7, 1.

[2] Bitchener, J., \& Knoch, U. (2010). The contribution of written corrective feedback to language development: A ten month investigation. Applied Linguistics, 31(2), 193-214. 
[3] Bitchener, J., \& Knoch, U. (2010b). Raising the linguistic accuracy level of advanced L2 writers with written corrective feedback. Journal of Second Language Writing, 19, 207-217

[4] Bitchener, J. (2012). A reflection on the 'language learning potential' of written CF. Journal of Second Language Writing, 21, 348-363.

[5] Bitchener, J. (2008). Evidence in support of written corrective feedback. Journal of Second Language Writing, 17, $102-118$.

[6] Bitchener, J., \& Knoch, U. (2009). The contribution of written corrective feedback to language development: A ten-month investigation. Applied Linguistics, 31(2), 193-214.

[7] Bitchener, J., \& Knoch, U. (2009). The value of a focused approach to written corrective feedback. ELT Journal, 63(3), 204211.

[8] Bitchener, J., Young, S. \& Cameron, D. (2005). The effect of different types of corrective feedback on ESL student writing. Journal of Second Language Writing, 14, 191-205.

[9] Bowles, M. A. (2011). Measuring implicit and explicit linguistic knowledge. Studies in Second Language Acquisition, 33(2), 247-271.

[10] Chandler, J. (2003). The efficacy of various kinds of error feedback for improvement in the accuracy and fluency of L2 student writing. Journal of Second Language Writing, 12, 267- 296.

[11] Ebadi, M. R., Mohd Saad, M. \& Nabeel, A. (2014). Corrective Feedback and Second Language Acquisition: Differential Contributions of Implicit and Explicit Knowledge. The Malaysian Online Journal of Educational Science, 2(2), 10-19.

[12] Ellis, R., Loewen, S., \& Erlam, R. (2006). Implicit and explicit corrective feedback and the acquisition of L2 grammar. Studies in Second Language Acquisition, 28, 339-368.

[13] Ellis, R., Sheen, Y., Murakami, M., \& Takashima, H. (2008). The effects of focused and unfocused written corrective feedback in an English as a foreign language context. System, 36, 353-371.

[14] Ellis, R. (2008). A typology of written corrective feedback types. ELT Journal, 63(2), 97-107.

[15] Ellis, R. (1991). Grammaticality judgments and second language acquisition. Studies in Second Language Acquisition, 13(2), 161-186.

[16] Farrokhi, F. \& Sattarpour, S. (2012). The effects of direct written corrective feedback on improvement of grammatical accuracy of high-proficient L2 learners. World Journal of Education, 2(2). Retrieved September 12, 2013, from: www.sciedu.ca/wje.

[17] Ferris, D. (2006). Does error feedback help student writers? New evidence on the short- and long-term effects of written error correction. In K. Hyland \& F. Hyland (Eds.). Feedback in second language writing: Context and issues, (pp.81-104). Cambridge: Cambridge University Press.

[18] Ferris, D. R. \& Roberts, B. (2001). Error feedback in L2 writing classes: How explicit does it need to be? Journal of Second Language Writing 10, 161-84.

[19] Hatch, E. \& Farhady, H. (1981). Research design and statistics for applied linguistics. Tehran: Rahnoma Publication

[20] Kubota, M. (1994). The role of negative feedback on the acquisition of the English dative alternation by Japanese college students of EFL. Institute for Research in Language Teaching Bulletin, 8, 1-36.

[21] Lalande, J. (1982). Reducing composition errors: An experiment. Modern Language Journal, 66, 140-149.

[22] Lyster, R. (2007). Learning and teaching languages through content: A counterbalanced approach. Amsterdam: Benjamins.

[23] Nunan, D. (2001). Aspects of task-based syllabus design. Linguistic issues. Retrieved July 12, 2007 from http: //www 3. telus.net/linguisticsissues/syllabusdesighn.html.

[24] Petchprasert, A. (2012). Feedback in second language teaching and learning. US-China Foreign Language, 10(4), 1112-1120.

[25] Robb,T., Ross, S., \& Shortreed, I. (1986). Salience of feedback on error and its effect on EFL writing quality. TESOL Quarterly, 20, 83-93.

[26] Schmidt, R. (1993). Interaction, acculturation and the acquisition of communicative competence. In N. Wolfson\& E. Judd, (Eds.), Sociolinguistics and language acquisition (pp. 137-174). Rowley, MA: Newbury House.

[27] Sheen, Y. (2007). The effect of focused written corrective feedback and language aptitude on ESL learners' acquisition of articles. TESOL Quarterly, 41, 255-83.

[28] Truscott, J. (1996). The case against grammar correction in L2 writing classes. Language Learning, 46, 327-369.

[29] Truscott J. \& Hsu, A.Y. (2008). Error correction, revision, and learning. Journal of Second Language Writing, 17, $292-305$.

[30] Yilmaz, Y. (2013). Relative effects of explicit and implicit feedback: The role of working memory capacity and language analytic ability. Applied Linguistics, 34(3), 344-368.

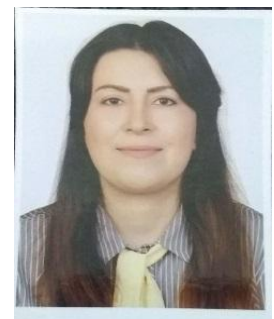

Fatemeh Azimi Amoli was an EFL teacher at different universities and English language institutes. She has $\mathrm{PhD}$. in Education. She graduated in Ilam University, Ilam, Iran in 2016. Recently, I was visiting scholarship in Ontario Tec University, Oshawa, ON, Canada. She is ESL teacher in an after school and Early Childhood Educator in Toronto. She published 20 papers, 2 books and is the reviewer of two journals in Taylor \& Francis, Springer and some national conferences. Her main interest is in teacher education, especially ESL teacher professional development, methodology, psycholinguistics and curriculum development. 